\title{
INTERNALISASI PENDIDIKAN KARAKTER DALAM PENGEMBANGAN SIKAP TANGGUNG JAWAB SOSIAL SISWA
}

\author{
Ni Ketut Sari Adnyani \\ Jurusan Ilmu Hukum FHIS Undiksha, Singaraja \\ Email: niktsariadnyani@gmail.com
}

\author{
Ni Nyoman Mandriani \\ SD Negeri 2 Datah, Amlapura \\ Ni Kadek Putus Asrini \\ SD Negeri 6 Tianyar, Amlapura
}

\begin{abstract}
Abstrak
Tujuan penelitian ini adalah : (1) untuk mengetahui pentingnya Pendidikan Karakter diberikan kepada peserta didik; (2) untuk mengetahui relevansi Pendidikan Karakter dalam mengembangakan sikap tanggung jawab sosial bagi peserta didik; dan (3) untuk mengetahui internalisasi Pendidikan Karakter dalam memperkaya khasanah pengetahuan peserta didik dalam rangka menumbuhkan sikap positif mengisi kemerdekaan. Metode penelitian, Penelitian ini menggunakan model penelitian dan pengembangan Pendidikan (Educational Research and Development). Proses pengembangan dan validasi produk pendidikan dalam penelitian ini adalah berupa pengembangan model pembelajaran nasionalisme berbasi local genius. Penelitian pada tahap Define dan design ini dilakukan pada setting penelitian: pendidik, sekolah, siswa dan perpustakaan. Tahap development, yaitu uji coba terbatas sesuai dengan desainnya akan dilakukan di SD Negeri 2 Datah dan SD Negeri 6 Tianyar dengan menggunakan setting kelas-kelas dalam pembelajaran PKn. Kelas-kelas mata pelajaran PKn yang dilibatkan pada tahap develompment dipilih secara purpossive (bertujuan) sesuai fokus penelitian. Penentuan sampel penelitian pada uji coba dilakukan secara random sampling. Hasil: Pendidikan Karakter diberikan kepada peserta didik, relevansinya berpengaruh terhadap sikap tanggung jawab sosial siswa.
\end{abstract}

Kata kunci: Internalisasi, Pendidikan Karakter, sikap tanggung jawab sosial

\begin{abstract}
The purpose of this research are: (1) to know the importance of Character Education given to the students; (2) to know the relevance of Character Education in developing social responsibility attitude for learners; and (3) to know the internalization of Character Education in enriching the knowledge of learners in order to cultivate a positive attitude to fill the independence. Research method, This research use Educational Research and Development model. The process of development and validation of educational products in this research is in the form of development of learning model of nationalism based on local genius. Research on Define and design stage is done on research setting: educator, school, student and library. Development phase, which is limited trial in accordance with the design will be done in SD Negeri 2 Datah and Elementary School 6 Tianyar by using setting classes in learning PKn. The classes of PKn subjects involved in the develompment stage are chosen purposively (purposively) according to the research focus. Determination of research samples in
\end{abstract}


trials conducted by random sampling. Outcome: Character Education is given to learners, its relevance influence to student's social responsibility attitude.

\section{Keywords: Internalization, Character Education, social responsibility attitude}

\section{Pendahuluan}

Nasionalisme merupakan jiwa dan semangat yang membentuk ikatan bersama, baikdalam hal kebersamaan maupun dalam hal pengorbanan demi bangsa dan negara (Ernes Renan, 1990). Nasionalisme terbangun ketika adanya penjajahan/imprialisme dalam bidang politik, hukum, ekonomi, sosial, budaya, pertahanan dan keamanan serta penjajahan fisik. Bangun nasionalisme Indonesia yang dideklarasikan pada tanggal 28 Oktober 1928 , oleh para pemuda yang menyatakan sumpah untuk berbahasa satu yaitu bahasa Indonesia, bertanah air satu yaitu tanah air Indonesia dan berbangsa satu yaitu bangsa Indonesia telah dibuktikan dengan adanya perlawanan bangsa Indonesia secara besarbesaran dengan mengorbankan harta benda dan nyawa. Terjadinya pertempuran di Surabaya yang dikenal dengan pertempuran

Surabaya (Nopember, 1945), pertempuran Medan area (Oktober 1945), Palagan Ambarawa (Nopember 1945), Bandung lautan api (Maret 1946), perang puputan Margarana di Bali (Nopember 1946) dan berbagai perlawanan lainnya merupakan bukti kongkrit nasionalisme rakyat Indonesia. Ketika penjajahan fisik telah meninggalkan Indonesia, maka nasionalisme akan mengalami pergeseran makna dan bentuk perjuangannya, bahkan tak jarang justru mengalami kepudaran/kemunduran jika tidak diinternalisasi, dipupuk, dirawat, dikembangkan dan diimplementasikan dalam bergai bidang kehidupan bermasyarakat, berbangsa dan bernegara (Suherni, 2016).

Secara faktual, kondisi ini memang menjadi kenyataan pada masyarakat Indonesia, yang saat ini sedang dihadapkan pada tatantangan yang amat berat berkaitan dengan memudarnya rasa nasionalisme dan terjadinya degradasi moral. Adanya gerakan radikalisme, berkembangnya organisasi yang menginginkan negara agama dan gerakan teorisme yang terjadi di bergai daerah untuk memecah belah persatuan dan kesatuan bangsa merupakan bukti kongkrit melunturnya nasionalisme (Suastika, 2014).

Persoalan ini terjadi disebabkan karena belum berfungsinya secara maksimal piranti-piranti sosial yang ada di masyarakat, termasuk piranti pendidikan. Proses internalisasi nilai-nilai nasionalisme dalam praktek pendidikan berlum diterjadikan secara maksimal. Praktik pendidikan yang dilangsungkan pada jenjang Sekolah Dasar sampai jenjang Pendidikan Tinggi dinilai belum mampu membangun secara utuh semangat nasionalisme pada setiap urat nadi anak didik. Sejalan dengan temuan penelitian Deny, (2009: iii) tentang integritas dalam pembentukan identitas bangsa untuk menumbuhkan budaya kewarganegaraan di Kota Medan, menunjukkan hasil pembelajaran PKn dan Sejarah masih berorientasi pada kemampuan kognitif dengan mengabaikan nilai-nilai nasionalisme yang semestinya menjadi kunci keberhasilan PKn dan Sejarah. Proses pembelajaran lebih banyak diupayakan pada pengembangan penguasaan materi, tanpa dibarengi dengan proses pengkajian yang bersifat kontekstual empirik tentang masalah-masalah kebangsaan, seperti berkembangnya faham radikalisme, terorisme, konflik antar etnis, berkembangnya politik identitas yang membahayakan bangsa dan negara, penjajahan intelektual, penjajangan ekonomi, penjajahan budaya, penjajahan sumber daya manusia dan penjajangan identitas kebangsaan (Winataputra, 2013). 
Sementara masyarakat Indonesia memiliki nilai-nilai lokal yang kuat untuk membangun rasa nasionalisme.

Permasalahan umum penelitian ini adalah bagaimanakah pengembangan model pembelajaran nasionalisme berbasis lokal genius dalam mata pelajaran PKn di tingkat Sekolah Dasar. Secara rinci masalah penelitian ini dapat dirumuskan sebagai berikut :

1) Bagaimanakah kondisi pembelajaran PKn di SD?.

2) Bagaimanakah proses pengembangan pengetahuan, sikap dan keterampilan nasionalisme siswa SD dalam praktek pembelajaran PKn selama ini ?

3) Bagaimanakah motivasi dan aktivitas siswa dalam pembelajaran PKn di SD di Kabupaten Karangasem?

Urgensi pendidikan nasionalisme secara yuridis terlegitimasi lewat dikeluarkannya Undang-Undang Negara Republik Indonesia No. 20 Tahun 2003 tentang Sistem Pendidikan Nasional, yaitu Pasal 3, menyebutkan bahwa pendidikan nasional berfungsi mengembangkan kemampuan dan membentuk karakter serta peradaban bangsa yang bermartabat dalam rangka mencerdaskan kehidupan bangsa. Ketentuan ini mengisyaratkan pentingnya pembentukan karakter dan jatidiri bangsa dalam proses pendidikan, sehingga terbangun rasa banga pada bangsa dan negara Indonesia. Kebanggaan akan bangsa dan negara akan menjadi sarana untuk memperkuat tali persudaraan, kebersamaan dan rasa saling memiliki antara masyarakat yang satu dengan masyarakat lainnya. Sehingga memunculkan komitmen untuk bersatu, walaupun terdiri dari berbagai macam suku, ras, agama, budaya, daerah dan golongan. Secara fakutal kondisi ini masih jauh dengan yang diharapkan, adanya ekstrakurikuler keagamaan, adanya kewjiban untuk menggunakan pakaian adat daerah tertentu di sekolah yang siswanya dominandari satu daerah dan terjadinya penyeragaman dalam berbagai dimensi pada sekolah merupakan bentuk dikriminasi dalam prkatek pendidikan yang berimplikasi pada sikap dan prilaku siswa dalam kehidupan bermasyarakat, berbangsa dan bernegara (Kompas, 27 Agutus 2016). Kondisi ini berkorelasi dengan gejala kehidupan bermasyarakat, berbangsa, dan bernegara yang menunjukkan semakin rendahnya kesadaran dan kecintaan terhadap Indonesia (Winataputra, 2013; Sapriya, 2015).

\section{Metode}

Penelitian ini menggunakan model penelitian dan pengembangan pendidikan (Educational Research and Development). Proses pengembangan dan validasi produk pendidikan dalam penelitian ini adalah berupa pengembangan model pembelajaran nasionalisme berbasi lokal genius (Borg and Gall, 1989). Adapun tahapan tersbut adalah define, design, development, dan dessemination (Thiagarajan et al, 1974).

Penelitian pada tahap Define dan design ini dilakukan di Kabupaten Karangasem pada setting penelitian: pendidik, sekolah, siswa dan perpustakaan atau pusat dokumentasi. Sedangkan pada

tahap development, yaitu uji coba terbatas sesuai dengan desainnya akan dilakukan di

sekolah, yaitu SD N 2 Datah, dan SD N 6 Tianyar dengan menggunakan setting kelas-kelas pada saat kegiatan pembelajaran PKn berlangsung. Kelas-kelas yang dijadikan sampel untuk mata pelajaran PKn yang dilibatkan pada tahap develompment dipilih secara purposive (bertujuan) sesuai dengan fokus penelitian.

Dalam melaksanakan pembelajaran PKn di Sekolah Dasar, guru perlu mengembangkan startegi/taktik yang tepat, dengan pendekatan-pendekatan dan modemodel belajar yang akan diterapkan serta didukung oleh metode dan media yang efektif. Hal ini akan membantu guru dalam memahami dan membantu siswa untuk berlatih mengamalkan nilai moral Pancasila dan budi pekerti yang dipelajari di sekolah. Dari sekian banyak pendekatan dan model 
serta metode pembelajaran, perlu dipilih beberapa pendekatan dan model pembelajaran yang sesuai dengan kebutuhan dan tingkat perkembangan siswa Sekolah Dasar (SD) serta sifat tujuan yang ingin dicapai dari proses pembelajaran $\mathrm{PKn}$ di SD.

Ada empat teknik pengumpulan data utama yang digunakan dalam penelitian tahap pertama dan kedua (define dan design) ini, yaitu pengumpulan data melalui kajian dokumen, melalui wawancara mendalam, observasi dan focus group discusstion. Untuk studi dokumen, instrumen penelitian yang digunakan adalah pedoman dan format studi/analisis dokumen.

Untuk studi melalui wawancara mendalam, peneliti mengembangkan pedoman wawancara secara mendalam yang tidak terstruktur (Miles and Huberman, 1992). Untuk observasi, peneliti mengembangkan pedoman observasi tidak terstruktur berkaitan dengan berbagai aktivitas pembelajaran di kelas dan aktivitas siswa dalam proses pembelajaran. Sedangkan untuk focus group discusstion instrument yang digunakan adalah format focus group discusstion yang dikembangkan sendiri oleh peneliti. Untuk penelitian tahap ketiga (development), pengumpulan data utama untuk memperoleh informasi tentang hasil belajar nasionalisme siswa dilakukan melalui tes objektif pilihan ganda tentang pengetahuan nasionalisme, untuk sikap nasionalisme siswa diperoleh melalui evaluasi diri sikap nasionalisme, dan pemberian format observasi tentang prilaku nasionalisme yang dikembangkan sendiri oleh peneliti.

Analisis data dalam penelitian ini disesuaikan dengan jenis sumber dan data yang diperoleh. Untuk analisis data tahap define dan design dilakukan secara kualitatif, yaitu mengkatagori dan mengklasifikasi data secara menyeluruh berdasarkan kaitan logisnya, kemudian ditafsirkan dalam keseluruhan konteks penelitian.

\section{Hasil dan Pembahasan \\ Kondisi Pembelajaran PKn di SD}

Pendekatan dalam pembelajaran

PKn pada prinsipnya lebih mengarah kepada pengembangan kurikulum atau pengorganisasian isi materi pelajaran. Ada delapan pendekatan, yang menurut Douglas Suparka (dalam Martorella, 1996) dapat digunakan dalam pembelajaran PKn, yaitu: 1. Evokasi (kesempatan), pendekatan ini menekankan pada inisiatif siswa untuk mengekspresikan dirinya secara spontan yang didasarkan pada kebebasan dan kesempatan. Pendekatan ini sering dihadapkan pada kendala kultural dan psikologikal, terutama pada masyarakat yang masih eksklusif. 2. Inkulkasi (menanamkan), pendekatan ini didasarkan pada sejumlah pertanyaan nilai yang telah tersusun oleh guru. Tujuannya untuk mempengaruhi dan mengarahkan siswa pada simpulan nilai yang sudah direncanakan. 3. Kesadaran, adalah bagaimana mengungkap dan membina kesadaran siswa tentang nilai-nilai tertentu yang ada pada dirinya atau orang lain. Kesadaran iktu akan tumbuh menajdi sesuatu yang menumbuhkan kesadaran tentang nilai atau seperangkat nilai tertentu. 4. Penalaran moral, dimana siswa dilibatkan dalam dilema moral sehingga keputusan yang diambil terhadap dilema moral harus dapat diberikan alasan-alasan moral yang rasional. 5. Analisis Nilai, suatu pendekatan yang mengajak siswa untuk mengkaji dan menganalisis nilai yang ada pada suartu media stimulus yang telah disiapkan guru dalam pembelajaran PKn. 6. Pengungkapan nilai, adalah upaya meningkatkan kesadaran diri (self awareness) dan memperhatikan diri sendiri, bukan pemecahan masalah. Pendekatan ini membantu siswa untuk menemukan dan memeriksa nilai mereka untuk menemukan keberartian dan rasa aman. 7. Komitmen, mengarahkan dan menekankan pada seperangkat nilai yang akan mendasari pola piker setiap guru yang bertanggung jawab. Terhadap pendidikan nilai dan moral. Dalam PKn yang menjadi komitmen dasarnya adalah nilai dan moral 
Pancasila dan UUD 1945. 8. Memadukan, menyatukan diri siswa dengan pengalaman dalam kehidupan riil yang dirancang oleh guru dalam proses pembelajaran. Proses menyatukan ini dimaksudkan agar siswa benar-benar mengalami secara langsung pengalaman-pengalaman yang dirancang oleh guru memlaui berbagai metode yang sesuai, seperti: metode partisipatori, simulasi, sosiodrama, studi proyek. Sebagai pendidikan nilai, dalam proses pembelajaran Pendidikan Kewarganegaraan (PKn) dituntut untuk: 1. Lebih mengenali dan memahami nilai-nilai inti pribadi dan masyarakat 2. Ber-inkuiri (filosofis dan rasional) terhadap nilai-nilai tersebut 3 . Mencoba dan menumbuhkan respon afektif dan emotif terhadap nilai-nilai tersebut 4 . Membuat putusan tentang tindakan yang paling tepat atas dasar inkuiri dan respon. Guru perlu mempertimbangkan startegi yang tepat dalam pembelajaran PKn, dari beberapa pendekatan dan model yang akan diterapkan. Hal ini akan membantu guru dalam memahami Pendidikan Kewarganegaraan (PKn) dan sekaligus membantu siswa untuk mengamalkan nilai moral Pancasila dan budi pekerti yang luhur, yang dipelajari di sekolah. Dari beberapa pendekatan dan model pembelajaran perlu dipilih yang sesuai dengan kebutuhan dan tingkat perkembangan siswa, sehingga proses pembelajaran lebih bermakna. Untuk menjembatani pemahaman tentang hubungan antara perasaan (feeling), pemikiran (though), dan tindakan (action) moralitas seseorang, perlu dikembangkan model pendidikan moral yang efektif. Semua model pembelajaran PKn biasanya mempunyai hubungan langsung maupun tidak langsung dengan proses yang terpisah antara caring, judging dan acting. Pemahaman secara umum terhadap ketiga proses tersebut (caring, judging, acting) akan membantu seorang guru dalam memahami model belajar secara efektif, yaitu: 1. Caring (perhatian), adalah istilah yang menunjukkan perilaku seseorang untuk menolong atau memperhatikan orang lain. Seseorang yang terdorong untuk membantu, memperhatikan dan memikirkan orang lain berarti juga memperhatikan kebutuhan atau minat atau perhatian orang lain yang membangkitkan kepedulian terhadap orang lian. Istilah itu juga mengandung suatu tingkat pemahaman social dan psikologikal tertentu. Memperhatikan dengan menolong orang lain yang dodorong oleh suatu tingkat perasaan tertentu sebenarnya tidak cukup dengan hanya merasakan kebutuhannya, akan tetapi hal itu juga menyangkut nkemampuan untuk mengetahuidan menyimpulkan kebutuhan dan minat orang lain. 2. Judging (Pertimbangan), adalah proses menilai dan mempertimbangkan yang tidak lepas dari nalar ( reasoning) walaupun antara keduanya harus dapat dibedakan. Dengan penalaran (reason though) atau pertimbangan (judge) sebuah moral sering menempatkan kesejahteraan orang lain menjadi taruhannya. Memang harus mempertimbangkan berbagai pihak yang terlibat dalam keputusan /penalaran kita. Misalnya "membunuh seseorang demi kepentingan negara" memerlukan kemampuan untuk membuat keputusan di antara berbagai bayangan tentang "baik" dengan penafsiran tandingan dengan yang"benar". Dalam membandingkan antara caring dan judging itu seseorang akan diahadapkan pada pertimbangan nilai (value judgment) yang mengandung alasan (reasoning). Namun sesuai dengan sifatnya, alasan tidak dapat diterapkan dalam satu kasus tertentu. Seperti pendapat yang menyatakan bahwa " membunuh orang adalah salah" tetapi bagaimana halnya dengan "membunuh untuk membela diri". Oleh karena itu pertimbangan moral memerlukan kemampuan untuk menilai minat yang saling bertentangan berdasarkan dasar/prinsip dan criteria yang konstan. 3 . Acting ( tindakan ), adalah bukanlah sesuatu yang bersifat moral atau immoral, di luar dari motivasi atau pertimbangan seseorang atau tindakan tidak memiliki status moral. Apa yang membuat tindakan sebagai moral adalah kualitas perhatian/ pertimbangan yang yang memandunya. Kerapihan, 
kebersihan dan kejujuran sering dianggap sebagai moral. Tetapi yang menjadi masalahnya adalah alas an-alsan yang melatarbelakangi mengapa kita melakukannya. Yang penting pada dasarnya adalah niat, bukan pamer supaya mendapat pujian. Walaupun tindakan bukan sebuah kategori moral, tanpa kesempatan untuk bertindak dan merefleksikan tindakan akan menghambat terjadinya proses pengembangan moral. Yang penting bagi guru, pendidikan moral bukanlah menyejajarkan antara peneyesuaian moral dengan moralitas, namun yang terpenting adalah bagaimana membantu siswa untuk memiliki otonomi moral.

\section{Proses pengembangan pengetahuan, sikap dan keterampilan nasionalisme siswa SD dalam praktek pembelajaran PKn selama ini}

Salah satu praktik pembelajaran yang disinyalir mampu menumbuhkan keterampilan nasionalisme siswa adalah melalui pembelajaran PKn. Melalui pembelajaran PKn, siswa dapat merasakan, menghayati dan mengamalkan prilaku patriotism dan nasionalisme dalam kehidupan sekolah. Siswa akan melatih kesadaran bernegara, mereflesi berdirinya berbangsa Indonesia, pengorbanan para pahlawan, bertangungjawab pada bangsa dan negara, peduli pada masalah sosial, mencintai karya bangsa sendiri, mengamalkan nilai-nilai budaya bangsa, berjuang demi bangsa dan negara serta rela berkorban demi bangsa dan negara.

Pada praktiknya pembelajaran PKn di SD N 2 Datah dan SD N 6 Tianyar masih jauh dari apa yang diharapkan. Penelitian Deny, (2009: iii) tentang integritas dalam pembentukan identitas bangsa untuk menumbuhkan kesadaran pesert didik, menunjukkan hasil pembelajaran PKn masih berorientasi pada kemampuan kognitif dengan mengabaikan keterampilan nasionalisme yang semestinya menjadi kunci keberhasilan pembelajaran .

Berangkat dari masalah siswa yang tidak mengikuti upacara, tidak hefal lagu- lagu Indonesia raya, tidak hafal pancasila, tidak mengibarkan bendera, tidak saling menghormati menemukan proses pembelajaran PKn pada jenjang SD masih bersifat exspositoris dengan mengandalkan wibawa guru, sehingga tidak mampu merangsang minat, kreativitas dan keterampilan siswa untuk berpartisipasi dalam mengatasi masalah-masalah kebangsaan yang terjadi pada masyarakatnya.

Praktik pembelajaran PKn masih kering dari proses melatih dan membiasakansikap nasionalisme dalam praktek pembelajaran. Padahal keberhasilan dari pembelajaran PLn adalah terbangunnya tangungjawab, kegigihan berjuangan untuk mengejar cita-cita, komitemen, jujur, berjuang demi bangsa dan neagara, mencintai budaya dan produk dalam negeri, menghormati otoritas negara, lambang negara, menghargai para pahlawan, rela berkorban demi bangsa dan negara. Salah satu persoalan dasar dalam praktek pembelajaran PKn adalah model pembelajaran dan model evaluasi yang diterapkan guru dalam pembelajaran PKn.

Urgen dalampengembangan sikap sosial, termasuk dalam pembelajaran PKn adalah model pembelajaran yang mengarahkan aktivitas guru dan siswa untuk mencapai kesadaran sejarah dan nasionalisme serta model evaluasi yang akan diterapkan guru yang dapat menunjang tercapainya prilaku nasionalisme siswa. Oleh karena itu, selain kemampuan dan keterampilan guru, model pembelajaran juga akan menjadi instrumen utama dalam menentukan keberhasilan pembelajaran PKn dalam membangun sikap nasionalisme siswa.

\section{Motivasi dan aktivitas siswa dalam pembelajaran PKn di SD di Kabupaten Karangasem}

Beberapa upaya juga telah dilakukan oleh guru SDdi Kabupaten Karangasem dalam mengemas mata pelajaran PKn untuk mengembangkan model belajar dan pembelajaran alternatif 
berbasis pada pendekatan budaya spiritual lokal masyarakat. Guru di SD N 2 Datah dan SD N 6 Tianyar telah mengembangkan model siklus belajar Tri Hita Karana dalam pembelajaran PKn di Sekolah Dasar. Hasilnya menunjukkan meningkatnya motivasi dan aktivitas siswa dalam mengembangkan sikap nasionalisme melalui implementasi nilai-nilai karakter yang dikembangkan dalam kehidupan sehari-hari siswa Sekolah Dasar.

\section{Kesimpulan}

Kondisi pembelajaran PKn di SD meyelaraskan dengan tingkat kebutuhan belajar siswa di jenjang tersebut, tahapan dan sintak pembelajaran pun dirancang sederhana menyesuaikan dengan tingkat kebutuhan belajar PKn peserta didik di level SD.

Proses pengembangan pengetahuan, sikap dan keterampilan nasionalisme siswa SD dalam praktek pembelajaran PKn selama ini melatih siswa untuk memiliki kesadaran bernegara, mereflesi berdirinya berbangsa Indonesia, pengorbanan para pahlawan, bertangungjawab pada bangsa dan negara, peduli pada masalah sosial, mencintai karya bangsa sendiri, mengamalkan nilai-nilai budaya bangsa, berjuang demi bangsa dan negara serta rela berkorban demi bangsa dan negara.

Guru di SD N 2 Datah dan SD N 6 Tianyar telah mengembangkan model siklus belajar Tri Hita Karana dalam pembelajaran PKn di Sekolah Dasar. Hasilnya menunjukkan meningkatnya motivasi dan aktivitas siswadalam belajar PKn.

\section{Daftar Pustaka}

Borg, W. R. and M. D. Gall. (1989). Educational Research: An Introduction. Fifth Edition. New York and London: Longman

Bali Post, 16 Mei 2017; 02 Juni 2017; 09 Mei 2017.

Deny Setiawan. (2009). Integritas dalam Proses Pembentukan Identitas Bangsa
Untuk Menumbuhkan Kesadaran Sejarah (Disertasi). Bandung: UPI.

Ernes. R. (1990). What is A Nation? Dalam Nation dan Narration: Kesatuan. Yogyakarta:Kanisius.

Joyce, B., \& Weil, M. (2009). Model of teaching. New Jersey: Prentice-Hall, Inc.

Kusnadi. (2006). Pengembangan Model Pembelajaran IPS-Geografi Berbasis Tauhid. Disertasi. Bandung: UPI.

Miles, B and Huberman, M. (1992). Analisis Data Kualitatif. Penerjemah Rohendi Rohedi. Jakarta; UI-Press.

Suherni, (2016). Sikap Nasionalisme Peserta Didik Pada Sma Negeri 1 Bangkala Kecamatan Bangkala Kabupaten Jeneponto. Makasar: Universitas Negeri Makassar.

Suhartono, (2001) Sejarah Pergerakan Nasional. Yogyakarta: Pustaka Pelajar.

Suastika, (2014) Nasionalisme Dalam Perpektif Postmodernisme, Poststrukturalisme dan Postkolonialisme. Singaraja: Media Komunikasi FIS

Tribun News com, 10 Maret dan 16 Mei 2017

Undang-Undang Republik Indonesia Nomor 20 Tahun 2003 Tentang Sistem Pendidikan Nasional. Jakarta: Departemen Pendidikan Nasional RI

Winataputra, U. (2013) Civic Education (Konteks, Landasan, Bahan Ajar dan Kultur Kelas).Bandung: Program Studi Pendidikan Kewarganegaraan Sekolah Pascasarjana UPI.

http://sdnkedungdoro308surabaya.blogspot. co.id/2012/05/strategi-pembelajaranpkn-sekolah-dasar.html. 